\title{
THE INFLUENCE OF ONLINE BRAND COMMUNITY, PRODUCT QUALITY, AND PRICE ON BRAND LOYALTY
}

\author{
Muhamad Faqih ${ }^{1}$, Tiladela Luhita ${ }^{2}$, \\ 1,2 Jurusan Manajemen, Fakultas Ekonomi dan Bisnis, Universitas Jenderal Soedirman, Jl, HR. Boenyamin \\ No. 708, Purwokerto 53122, Jawa Tengah, Indonesia \\ E-mail Corresponding author: tiladela.luhita@gmail.com
}

\begin{abstract}
The purpose of this study is to examine the influence of online brand community, product quality, and price on brand loyalty study. To this end, questionnaires were distributed to 96 respondents selected purposively based on three criteria: aged at least 17 years old, having used Xiaomi smartphones for at least one year, and registered as members of Mi Community for at least one year. Data analysis was performed using multiple regression analysis. The results show that the online brand community, product quality, and the price had a positive influence on brand loyalty both partially and simultaneously.
\end{abstract}

Keywords: Online Brand Community, Product Quality, Price, Brand Loyalty

\section{INTRODUCTION}

Nowadays, the smartphone has been everyone's primary need in Indonesia. Smartphone users in Indonesia are increasing every year. Data from eMarketer suggests that in the last five years smartphone users in Indonesia grew from 38.3 million in 2014 to 52.2 million, 69.4 million, 86.6 million and 103 million in 2018. With such a large number, according to eMarketer, Indonesia will become the country with the fourth largest active smartphone user in the world after China, India and the United States. This makes Indonesia an attractive market for smartphone manufacturers. Various new smartphone brands have emerged so that the smartphone market competition is getting tougher, and increasing competition requires smartphone manufacturers to maintain their brand loyalty. Customer retention will generally be more profitable than attracting new customers because the cost of attracting new customers can be five times the cost of retaining existing customers (Kotler,2007:207). Brand loyalty is a measure of the customer relationship to a brand. This measure can provide information on whether or not a customer may switch from a product brand to another brand, especially if there are changes in price, product quality or other attributes. Today's development of Internet technology enables us to build a brand community real world, but also in cyberspace or better known as an online brand community. According to Fuller et al. (2007), an online brand community is a brand community that occurs in a virtual environment where members interact through internet media such as chat rooms, newsgroups and discussion forums to exchange and share information about the brand. Another contributing factor to brand loyalty is product quality. According to Kotler and Armstrong (2001: 99), product quality is everything that the market offers to attract consumers' attention and purchases by satisfying their desires or needs. As suggested by Peter Drucker, customers are always looking for products that suit their needs and desires, especially if the product is for long-term use purposes such as a smartphone. When the quality of a brand's products is maintained or even improved, customers will likely continue to buy from the brand, but if the quality of a product decreases, the customer will switch to rival brands 
offering better quality. Jagad's (2011) study shows that product quality has a positive influence on brand loyalty.

Another factor that can determine brand loyalty is the product price. According to Kotler (2002), price is the value of goods or services measured by an amount of money based on that value a person or company is willing to release goods or services to another party. Loyal customers will also pay attention to the price of the product they use. If the price set is in accordance with their purchasing power, they will likely remain loyal to the brand, but when the price goes up, they will look for rival brands that have the same quality but lower prices.

\section{PROBLEM STATEMENTS}

1. Does the online brand community have a positive influence on Xiaomi brand loyalty?

2. Does the product quality have a positive influence on Xiaomi brand loyalty?

3. Does the price have a positive influence on Xiaomi brand loyalty?

\section{RESEARCH HYPOTHESES}

H1: The online brand community has a positive influence on Xiaomi brand loyalty

$\mathrm{H} 2$ : The product quality has a positive influence on Xiaomi brand loyalty

H3: The price has a positive influence on Xiaomi brand loyalty

\section{RESEARCH METHOD AND TECHNIQUE OF DATA ANALYSIS}

\section{Research Design}

This research is a survey study using questionnaires to collect data.

\section{Research Population and Sample}

The research population was respondents aged at least 17 , registered as members of the $\mathrm{Mi}$ Community for at least 1 year, having used Xiaomi smartphones for at least 1 year.

\section{Data Type and Source}

\section{Primary Data}

Primary data is data that is collected by a researcher from first-hand sources (Suliyanto, 2006: 131). In this study, data were directly collected from respondents through questionnaires about the online brand community, product quality, price and brand loyalty of Xiaomi smartphone users.

\section{Secondary Data}

Secondary data in this study were data obtained from literature, websites, journal articles, and previous research reports.

\section{Data Collection Technique}

The field study was carried out by distributing questionnaires to respondents containing a list of statements to figure out the effect of the online brand community, product quality, and price on brand loyalty. The questionnaire distribution was shared online using Google Forms.

Data were also obtained from previous research publications, books, journal articles, and articles from the internet related to the online brand community, product quality, price and brand loyalty. 
Page: 28-39

ISSN:

DOI:

\section{Conceptual and Operational Definition}

\begin{tabular}{|c|c|c|c|}
\hline Variable & $\begin{array}{c}\text { Operational } \\
\text { Definition }\end{array}$ & Dimension & Indicator \\
\hline \multirow{3}{*}{$\begin{array}{l}\text { Online Brand } \\
\text { Community (X1) is } \\
\text { a specialized and } \\
\text { borderless } \\
\text { community } \\
\text { established upon a set } \\
\text { of social relationship } \\
\text { structures among fans } \\
\text { of certain brands } \\
\text { (Muniz and O'Guin, } \\
\text { 2001) }\end{array}$} & \multirow[t]{3}{*}{$\begin{array}{l}\text { An online } \\
\text { community } \\
\text { consisting of Xiaomi } \\
\text { brand fans }\end{array}$} & $\begin{array}{l}\text { Consciousness of } \\
\text { kind }\end{array}$ & $\begin{array}{l}\text { 1. Level of knowledge } \\
\text { about the community } \\
\text { 2. Level of knowledge } \\
\text { about the brand } \\
\text { 3. Level of trust towards } \\
\text { the community }\end{array}$ \\
\hline & & Ritual and tradition & $\begin{array}{l}\text { 4. Level of active } \\
\text { involvement in sharing } \\
\text { stories with fellow } \\
\text { community members } \\
\text { 5. Level of desire to } \\
\text { participate in } \\
\text { community activities or } \\
\text { events }\end{array}$ \\
\hline & & Moral Responsibility & $\begin{array}{l}\text { 6. Level of active } \\
\text { involvement in finding } \\
\text { information about the } \\
\text { brand } \\
\text { 7. Level of active } \\
\text { involvement in } \\
\text { responding to issues of } \\
\text { brand use expressed by } \\
\text { fellow community } \\
\text { members } \\
\text { 8. Level of trust in } \\
\text { information provided } \\
\text { by community } \\
\text { members }\end{array}$ \\
\hline \multirow{6}{*}{$\begin{array}{l}\text { Product quality } \\
\text { (X2) is a consumer } \\
\text { assessment of the } \\
\text { advantages or } \\
\text { features of a product } \\
\text { (Tjiptono, 2008) }\end{array}$} & \multirow{6}{*}{$\begin{array}{l}\text { Consumer } \\
\text { assessment of the } \\
\text { advantages or } \\
\text { features of Xiaomi } \\
\text { smartphones }\end{array}$} & Features & 1. Product features \\
\hline & & Serviceability & $\begin{array}{l}\text { 2. The ease of repairing } \\
\text { the product }\end{array}$ \\
\hline & & Durability & 3. Product durability \\
\hline & & Aesthetics & $\begin{array}{ll}\text { 4. } & \text { Product attractiveness } \\
\text { 5. } & \text { Attractive design }\end{array}$ \\
\hline & & Perceived quality & $\begin{array}{l}\text { 6. Perception of the } \\
\text { product quality }\end{array}$ \\
\hline & & Reliability & 7. Product reliability \\
\hline $\begin{array}{l}\text { Harga }(\mathbf{X 3}) \\
\text { can be narrowly } \\
\text { defined as the } \\
\text { amount of money } \\
\text { billed for a product or } \\
\text { service, or it can be } \\
\text { broadly defined as }\end{array}$ & $\begin{array}{l}\text { The amount of value } \\
\text { that consumers } \\
\text { exchange for owning } \\
\text { or using a Xiaomi } \\
\text { smartphone, which } \\
\text { allows the company } \\
\text { to make a profit. }\end{array}$ & & $\begin{array}{ll}\text { 1. } & \text { Price affordability } \\
\text { 2. } & \text { Price to quality ratio } \\
\text { 3. } & \text { Price competitiveness } \\
\text { 4. } & \text { Price to performance } \\
\text { ratio }\end{array}$ \\
\hline
\end{tabular}


the amount of value

that consumers

exchange for the

benefit of owning

and using a product

or service that allows

a company to get a

reasonable profit by

being paid for the

customer value they

create (Kotler and

Amstrong,

2012:345)

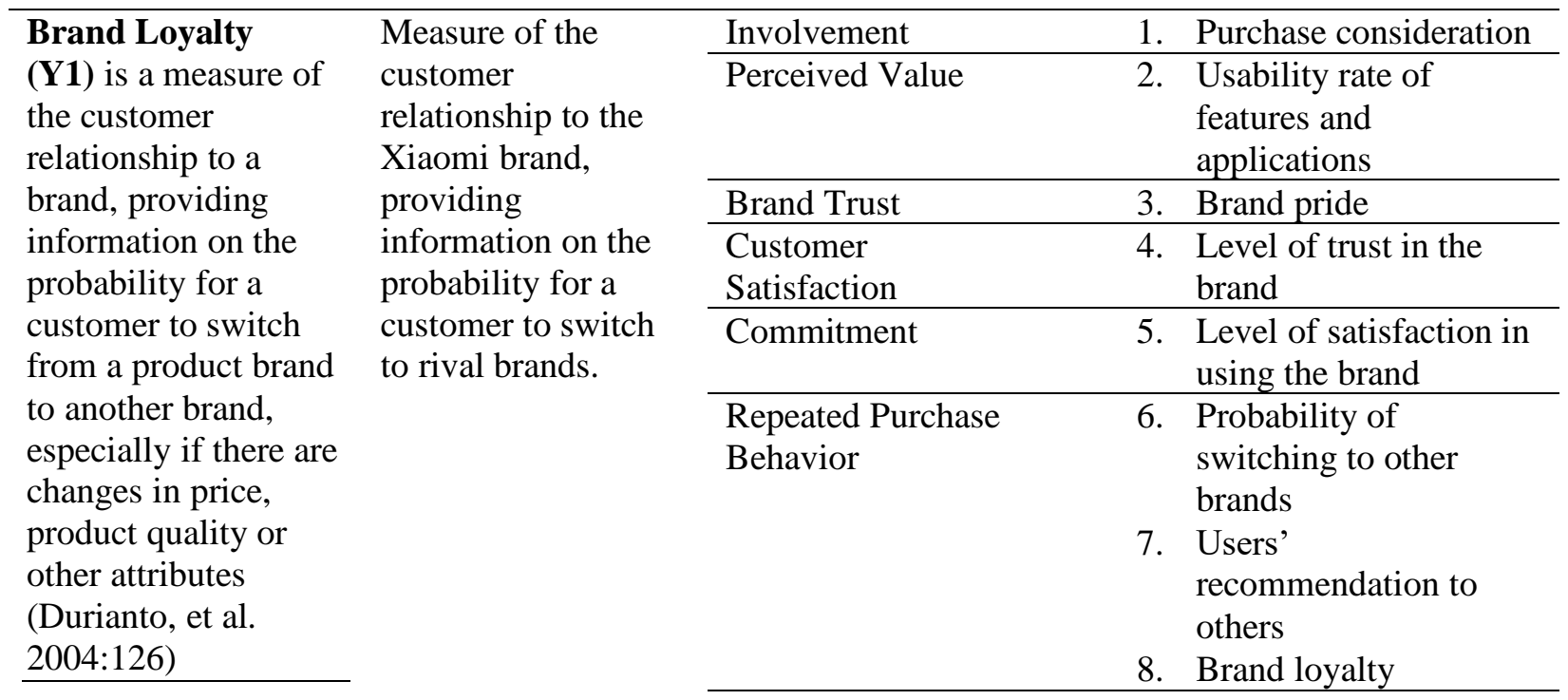

\section{Method of Analysis}

\section{Scale of Measurement}

The measurement scale is used as a reference standard to determine the length of the interval so as to produce quantitative data. This study used the Likert scale measurement. According to Suliyanto (2006: 82), the Likert scale is used to measure individual responses to social objects. The measurement used the following five scales:
a. Strongly Agree
(SA) score 5
b. Agree
(A) score 4
c. Neutral
(N) score 3
d. Disagree
e. Strongly Disagree
(D) score 2
(SD) score 1

\section{Instrument Test}

\section{a. Validity Test}

A validity test is used to measure the validity of the questionnaire. The questionnaire is said to be valid if the questionnaire items are able to reveal something that will be measured.

\section{b. Reliability Test}

The reliability test aims to determine the consistency of measurements when repeated measurements are made. This is done using the Cronbach's alpha coefficient (Sugiyono, 2009: 132). 


\section{Classical Assumption Test}

The purpose of the classical assumption test is to figure out if the obtained regression model deviates from the classical assumptions. If it is found to have deviated, the obtained regression equation is said not efficient to generalize the sample to the population because there will be bias, meaning that the results of the study are influenced not only by the studied variables but also by other factors.

\section{a. Normality Test}

The normality test is carried out to find out whether the standardized residual values in the regression model are normally distributed. They are said to be normally distributed if most of them are close to the average value. This study used the nonparametric Kolmogorov-Smirnov statistical approach to carry out the normality test. The standardized residual values are normally distributed provided that the observed $\mathrm{Z}<$ critical $\mathrm{Z}$ or the Sig. value $>$ alpha value (Suliyanto, 2011:78).

\section{b. Multicollinearity Test}

The purpose of the multicollinearity test is to determine if there is a high or perfect correlation between independent variables. If that is the case, the regression model is said multicollinear. The multicollinearity can be seen from the variance inflation factor (VIF) value of each independent variable. If the VIF value is above 10 , the regression model is stated not multicollinear (Suliyanto, 2011:80).

\section{c. Heteroskedasticity Test}

The heteroskedasticity test is aimed to figure out if there is a deviation from classical assumptions. The heteroskedasticity test in this study was conducted using the Glejser test by regressing the independent variables to the absolute residual value. If the significance value between the independent variable and its absolute residual (e), if the probability value > alpha value (0.05), it can be ascertained that the model is not heteroscedastic (Suliyanto,2011:98).

\section{Multiple Regression Analysis}

Generally, the multiple linear regression analysis is performed to the influence of two or more independent variables $(\mathrm{X})$ on one dependent variable (Y) (Ghozali, 2011), in the case of this study was the influence of online brand community, product quality, and price on brand loyalty.

\section{Hypothesis Testing}

The hypothesis testing was performed using the adjusted coefficient of determination test, $\mathrm{F}$ test and $\mathrm{t}$ test.

\section{RESULT OF DATA ANALYSIS}

\section{Validity and Reliability Test}

The result of the validity test using the Pearson's product moment test shows that the observed $r$ values of all questionnaire items were above the critical $r$ of 0.361 , meaning that all questionnaire items of all variables were valid and hence the questionnaire was feasible to be used as a data collection instrument.

The reliability test was performed using Cronbach's alpha test. The results are presented in Table 1.

Table 1. Result of Reliability Test

\begin{tabular}{lccc}
\hline \multicolumn{1}{c}{ Variable } & Observed r & Critical r & Note \\
\hline $\begin{array}{l}\text { Online Brand } \\
\text { Community } \\
\text { (X1) }\end{array}$ & 0.815 & 0.361 & Reliable \\
$\begin{array}{l}\text { Product Quality } \\
\text { (X2) }\end{array}$ & 0.687 & 0.361 & Reliable \\
$\begin{array}{l}\text { Price (X3) } \\
\text { Brand Loyalty }\end{array}$ & 0.789 & 0.361 & Reliable \\
$(Y)$ & 0.893 & 0.361 & Reliable \\
\hline
\end{tabular}

Table 1 shows that the observed $r$ values of variables online brand community $\left(\mathrm{X}_{1}\right)$, product quality $\left(\mathrm{X}_{2}\right)$, price $\left(\mathrm{X}_{3}\right)$, and brand loyalty $(\mathrm{Y})$ are 
above the critical value $(0,361)$, meaning that all questionnaire items of all variables were reliable.

\section{Multiple Regression Analysis}

\section{Table 2. Multiple Regression Analysis}

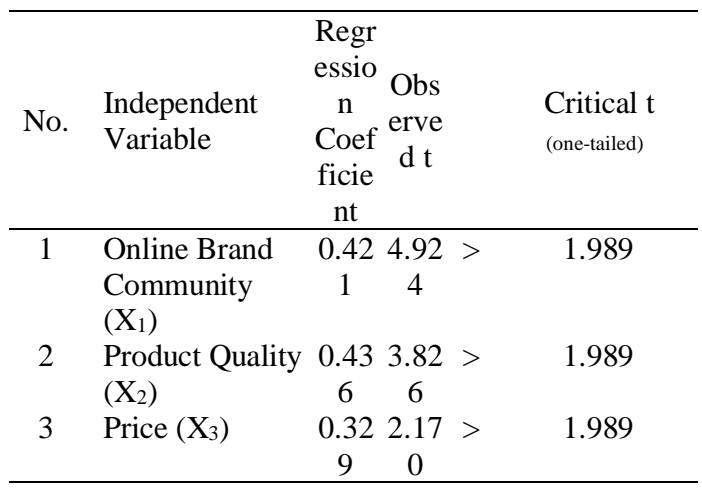

Based on the results of the SPSS statistical calculation presented in Table 2, the following multiple regression equation was generated:

$\mathrm{Y}=0.273+0.421 \mathrm{X}_{1}+0.436 \mathrm{X}_{2}+0.329 \mathrm{X}_{3}+\mathrm{e}$ The constant value of 0.273 shows that every increase in the variables online brand community, product quality, and price contributes to brand loyalty as much as 0.273 .

The coefficient value of 0.421 means that every increase in the variable online brand community contributes to brand loyalty as much as 0.421 .

The coefficient value of 0.436 means that every increase in the variable product quality contributes to brand loyalty as much as 0.436 .

The coefficient value of 0.329 means that every increase in price contributes to brand loyalty as much as 0.329 .

\section{Classical Assumption Test}

\section{Normality Test}

Table 3. Normality Test

\begin{tabular}{cccc}
\hline Variable & $\begin{array}{c}\text { Kolmogorov- } \\
\text { Smirnov } \\
\text { score }\end{array}$ & $\begin{array}{c}\text { Asymp. } \\
\text { Sig. }\end{array}$ & Note \\
\hline $\begin{array}{c}\text { Standardized } \\
\text { Residual }\end{array}$ & & 0.734 & $\begin{array}{c}\text { Normally } \\
\text { distributed }\end{array}$ \\
\hline
\end{tabular}

Table 3 shows that the Asymp. Sig. (2-tailed) value of the Kolmogorov-Smirnov $\mathrm{Z}$ test was 0.734 (>0.05), meaning that data were normally distributed.

\section{Multicollinearity Test}

Table 4. Multicollinearity Test

\begin{tabular}{llcl}
\hline \multirow{2}{*}{ No $\begin{array}{l}\text { Independent } \\
\text { Variable }\end{array}$} & $\begin{array}{l}\text { VIF } \\
\text { Val } \\
\text { ue }\end{array}$ & Note \\
\hline 1 & Online Brand & 1.2 & Not multicollinear \\
& Community $\left(\mathrm{X}_{1}\right)$ & 82 & \\
2 & Product Quality & 1.3 & Not multicollinear \\
& $\left(\mathrm{X}_{2}\right)$ & 62 & \\
3 & Price $\left(\mathrm{X}_{3}\right)$ & 1.2 & Not multicollinear \\
& & 87 & \\
\hline
\end{tabular}

Table 4 shows that the variance inflation factor (VIF) values of all of the variables online brand community $\left(\mathrm{X}_{1}\right)$, product quality $\left(\mathrm{X}_{2}\right)$, and price $\left(\mathrm{X}_{3}\right)$ were lower than 10 , meaning that there was no multicollinearity.

\section{Heteroskedasticity Test}

Table 5. Summary of Heteroskedasticity Test Result

\begin{tabular}{clcc}
\hline \multirow{2}{*}{ No } & $\begin{array}{l}\text { Independent } \\
\text { Variable }\end{array}$ & Sig & Note \\
\hline 1 & Online Brand & 0.8 & Not heteroscedastic \\
& Community & 02 & \\
& $\left(\mathrm{X}_{1}\right)$ & & \\
2 & Product Quality & 0.4 & Not heteroscedastic
\end{tabular}


Page: 28-39

DOI:

$\left(\mathrm{X}_{2}\right) \quad 50$

3 Price $\left(\mathrm{X}_{3}\right) \quad 0.0 \quad$ Not heteroscedastic

Table 5 shows that the significance values of the variables online brand community $\left(\mathrm{X}_{1}\right)$, product quality $\left(\mathrm{X}_{2}\right)$, and price $\left(\mathrm{X}_{3}\right)$ were higher than 0.05 , meaning that there was no

heteroscedasticity in the regression model.

\section{Hypothesis Testing}

\section{Table 6. Hypothesis Testing}

\begin{tabular}{|c|c|c|c|c|c|}
\hline No. & Hypothesis & $\begin{array}{l}\text { Regression } \\
\text { Coefficient }\end{array}$ & $\begin{array}{c}\text { Observed } \\
\mathrm{t}\end{array}$ & $\begin{array}{c}\text { Critical } \mathrm{t}_{\text {(one- }} \\
\text { tailed) }\end{array}$ & Note \\
\hline 1 & $\begin{array}{l}\text { Influence of Online Brand Community } \\
\text { on Brand Loyalty }\end{array}$ & 0.093 & $4.924>$ & 1.989 & Hypothesis accepted \\
\hline 2 & $\begin{array}{l}\text { Influence of Product Quality on Brand } \\
\text { Loyalty }\end{array}$ & 0.086 & $3.826>$ & 1.989 & Hypothesis accepted \\
\hline 3 & Influence of Price on Brand Loyalty & 0.049 & $2.170>$ & 1.989 & Hypothesis accepted \\
\hline \multicolumn{6}{|c|}{ Alpha $=0.05$} \\
\hline \multicolumn{6}{|c|}{ Constant value $=0.273$} \\
\hline \multicolumn{6}{|c|}{ Adjusted $\mathrm{R}^{2}=0.499$} \\
\hline \multicolumn{6}{|c|}{ Observed F $=32.524$} \\
\hline
\end{tabular}

Table 6 shows that the adjusted coefficient of determination $\left(\mathrm{R}^{2}\right)$ value was 0.499 , meaning that brand loyalty is influenced by online brand community, product quality, and price as much as $49.90 \%$, and the other $50,10 \%$ is influenced by factors other than the three studied variables in the regression model.

The observed $\mathrm{F}$ of 32.524 is higher than the critical $F$ of 2.70 , using the degree of freedom formula $\mathrm{k}-1$ and $\mathrm{n}-\mathrm{k}$. This result shows that the online brand community, product quality, and price simultaneously have a significant influence on brand loyalty.

Using the error margin $(\alpha)$ of 0.05 and degree of freedom $(\mathrm{n}-\mathrm{k}$, where $\mathrm{n}=96$ and $\mathrm{k}=3)$, the critical $t$ value (one-tailed) was 1.989. The observed $t$ value of the online brand community was 4.924, the observed t value of product quality was 3.826, and the observed $t$ value of price was 2.170 .

\section{DISCUSSION}

\section{Influence of Online Brand Community on Brand Loyalty}

The results of the study show that the online brand community (Mi Community) had a positive influence on the brand loyalty of customers in Xiaomi smartphones in the City of Purwokerto. In this study, online brand community was viewed in terms of eight indicators including level of knowledge about the community, level of knowledge about the brand, level of trust towards the community, level of active involvement in sharing stories with fellow community members, level of desire to participate in community activities or events, level of active involvement in finding information about the brand, level of active involvement in responding to issues of brand use expressed by fellow community members, and level of trust in information provided by community members. 
The existence of an online brand community makes users' needs related to information about the products they use and the latest products from Xiaomi smartphones can be accommodated. Also, in the Mi Community, users will get information about the latest software updates, tips and tricks to maximize the features of their smartphones. Because of all of this information, the online brand community becomes very important, and through this platform, Xiaomi users can get to know each other better and get closer to the brand, creating an attachment between fellow users, as well as between users and brands so that they become loyal users of the Xiaomi brands. This is something users of other smartphone users do not have.

Empirically, Mi Community shows evidence that the online brand community has an influence on Xiaomi smartphone brand loyalty. This finding is in line with that of Makayasa's (2015) study stating that the online Android community on Indonesian Internet forum Kaskus had a significant influence on brand loyalty. Similar findings were also suggested by other studies (e.g., Siregar, et al., 2017; Riyansa, 2017).

\section{Influence of Product Quality on Brand Loyalty}

This study also found that product quality had a positive influence on brand loyalty. In this study, product quality was measured using seven indicators as follows: product features, the ease of repairing the product, product durability, product attractiveness, attractive design, perception of the product quality, and product reliability.

In this study, the majority of respondents rated the Xiaomi smartphones to have good quality in terms of design and durability thanks to their metal build quality and Snapdragon chipsets and Xiaomi offered an 18-month warranty. In terms of operation, Xiaomi smartphones are also userfriendly, equipped with a good antenna that enables them to receive good mobile coverage, and have complete support features that cannot be found in other smartphones such as, Mi Cloud, Mi Remote, Mi Drop, and so on.
The finding of this study is consistent with that of a previous study conducted by Oktaviani (2016) suggesting that product quality had a positive influence on brand loyalty. Likewise, Jagad's (2011) study also found that product quality had a positive influence on brand loyalty of Canon EOS 5D mark II users. Other previous studies (e.g. Benny, 2014; Dewi \& Suasana, 2014) revealed similar findings.

\section{Influence of Price on Brand Loyalty}

This study also found that price had a positive influence on brand loyalty. In this study, the price was measured using four indicators: price affordability, price to quality ratio, price competitiveness, and price to performance ratio. The majority of respondents deemed that Xiaomi smartphones had a good price to quality ratio and price to performance ratio. In addition, they believed that the prices of Xiaomi smartphones were affordable and competitive. Compared with their rivals, Xiaomi smartphones offered more value for money because customers could get luxury features usually found on flagship smartphones with lower prices.

This finding is in agreement with those of some previous studies (e.g., Saputra, 2014; Kotib, 2013; Pranata, 2017) that price had a positive influence on brand loyalty.

\section{CONCLUSION AND IMPLICATION}

\section{Conclusion}

Based on the results of the study, it could be concluded that: (1) Online brand community has a significant positive influence on brand loyalty in Xiaomi smartphone users registered as members of Mi Community, meaning that the online brand community makes Xiaomi smartphones users loyal customers of Xiaomi brands. The better the information and the features provided in the Mi Community platform, the better the brand loyalty. (2) Product quality has a significant positive influence on brand loyalty in Xiaomi smartphone users, meaning that the better the quality of Xiaomi smartphones, the more loyal their customers and that the better the quality of Xiaomi smartphones, the better the brand 
loyalty. (3) Product quality has a significant positive influence on brand loyalty in Xiaomi smartphone users, meaning that the better price to quality ratio, the more loyal the customers. (4) Simultaneously, the online brand community, product quality, and price have a positive influence on brand loyalty. If Xiaomi smartphone users benefit from the existence of the online brand community, good product quality, good price to quality ratio, and price affordability, they are likely to continue to be loyal to Xiaomi.

\section{Implication}

The above findings may imply that (1) Xiaomi needs to improve the quality of the $\mathrm{Mi}$ Community platform so as to meet the needs of their customers. With a good Mi Community platform, Xiaomi will be able to maintain good relations with its customers. Several strategies can be carried out by Xiaomi to improve their online brand community; for example, giving rewards to members who actively contribute to the $\mathrm{Mi}$ Community and holding routine offline activities to increase engagement between fellow members of the Mi Community and between members and the brand. Such online activities This offline activity can be a means of education and marketing Xiaomi's latest products and services. (2) Xiaomi needs to continuously improve the quality of their products to maintain customer loyalty to their brand. This can be done; for example, by improving the quality of the camera on their smartphones and expanding their service center networks. In addition, Xiaomi needs to extend its smartphone warranty period to 24 months as its rivals have done. (3) Xiaomi needs to improve its smartphone affordability and monitor the prices of its rivals so as to prevent their customers from switching to other brands. Furthermore, Xiaomi needs to reaffirm its stance as an affordable but luxury smartphone producer.

\section{Limitation}

The fact that the data collection was carried out by distributing online questionnaires through Google Forms could potentially be biased because some respondents might inaccurately fill out the questionnaires as they had no direct contact with the researchers. In addition, openended items should have been included in the questionnaires to better document the respondents' personal opinions. Based on the research gap from the results of some previous studies, the researchers investigated the influence of online brand community, product quality, and price on brand loyalty. Further studies may follow up this study by including other variables such as customer satisfaction, brand image, and promotion. 


\section{REFERENCES}

Brogi, Stefano. (2013). Online Brand Communities: A Literature Review. Procedia - Social and Behavioral Sciences. $\quad 109 . \quad 385-389$. 10.1016/j.sbspro.2013.12.477.

Brogi, Stefano et al.,(2013). The Effects of Online Brand Communities on Brand Equity in the Luxury Fashion Industry. International Journal of Engineering Business Management Special Issue on Innovations in Fashion Industry. DOI: $10.5772 / 56854$

Benny, Deviana dan Sukartaatmadja, Iswandi.(2014).Pengaruh kualitas produk dan kualitas pelayanan terhadap loyalitas merek.STIE Kesatuan Bogor

Cahyaning Dewi, Ni Nyoman Ayu Suri Tri; Suasana, I Gusti Agung Ketut Gede.(2014). Pengaruh kualitas produk, citra merek, dan materialisme terhadap loyalitas merek pengguna produk apple di kota denpasar. $E$ Jurnal Manajemen, [S.1.], v. 3, n. 3, mar. .ISSN 2302-8912. Available at: $<$ https://ojs.unud.ac.id/index.php/Ma najemen/article/view/7282>. Date accessed: 08 Oktober 2019

Durianto, D., Sugiarto, \& Sitinjak, T.(2001). Strategi menaklukan pasar melalui riset ekuitas dan perilaku merek. Jakarta: PT. Gramedia Pustaka Utama.

Durianto, D., Sugiarto, \& Sitinjak, T.(2004). Strategi menaklukan pasar melalui riset ekuitas dan perilaku merek. Jakarta: PT. Gramedia Pustaka Utama.

Gounaris, S. dan Stathakopoulos, V.(2004). Antecedents and consequences of brand loyalty : an empirical study. Journal of Brand Management, 11(4),283-306.
Gipson, Daniel Lord dan Tricahyono Dodie.(2015). Pengaruh brand community terhadap brand loyalty studi kasus Kymco Group Bandung.eProceeding of Management : Vol.2, No.3Desember 2015; p 2903

Hur, W. Ahn, K. and Kim, M. (2011). Building brand loyalty through managing brand community commitment. International Journal of Management Decision, Vol. 49 No. 7, pp. 11941213.

Jagad, Langlang.(2011). Pengaruh kualitas produk terhadap kepercayaan merek serta implikasinya pada loyalitas merek.S2 thesis. Universitas Pendidikan Indonesia

Jr, Albert M. Muniz and O'Guinn, Thomas C. (2001). Brand Community. Journal Of Consumer Research, University Of Illinois. Vol 27, No. 4, pp. 412-432

Kotib, Muchamad Ali.(2013). Pengaruh kepuasan konsumen, harga, promosi dan kualitas layanan terhadap loyalitas merek pengguna kartu Indosat Mentari di desa Papringan Kudus.Skripsi. Universitas Muria Kudus

Kotler,Philip.(2002). Manajemen Pemasaran, Edisi Millenium, Jilid 2, PT Prenhallindo, Jakarta

Kotler, Philip.(2007). Manajemen Pemasaran, Jilid 2, Edisi 12, PT Indeks., New Jersey.

Kotler, dan Keller. (2012). Manajemen Pemasaran.

\section{Edisi 12. Jakarta: Erlangga}

Makayasa, Adi.(2015). Pengaruh brand community terhadap loyalitas merek dengan sistem operasi android Universitas Pendidikan Indonesia 
DOI:

Repository.upi.edu

perpustakaan.upi.edu

Mardino, Mochamad dan Tricahyono, Dodie.(2015).Pengaruh brand community terhadap brand loyalty (studi kasus pada komunitas Naked Wolves Indonesia.e-Proceeding of Management : Vol.2,No.3 Desember 2015; p 2355

Nugroho, Aditya Catur. (2017).Pengaruh Harga, kepuasan konsumen, dan kualitas produk terhadap loyalitas merek sepeda motor Honda.Skripsi. Universitas Muhamadiyah Surakarta.

Oktaviani, Rani.(2016).Pengaruh kualitas produk, kepercayaan merek,dan kepuasan konsumen terhadap loyalitas merek.Skripsi. Universitas Negeri Yogyakarta.

Riyansa, Ardi. (2017). Pengaruh brand community terhadap loyalitas merek scooter matic Vespa Piaggio. Skripsi. Universitas Lampung

Saputra, Angga.(2014).Pengaruh harga, kualitas, nilai yang dirasakan, dan pelayanan terhadap loyalitas merek pada konsumen KFC di Surabaya. STIE Perbanas Surabaya

Siregar et. al. (2017). Pengaruh brand community terhadap loyalitas merek (studi pada komunitas Grand Vitara). Universitas Islam Bandung. Prosiding Manajemen Volume 3, No. 2 Tahun 2017

Sugiyono (2015). Metode Penelitian \& Pengembangan Research and Development. Penerbit AlfaBeta. Bandung.

Suliyanto. (2006). Metode Riset Bisnis. Yogyakarta: Penerbit Andi.
Suliyanto. (2011). Ekonometrika Terapan: Teori dan Aplikasi dengan SPSS. Yogyakarta: Andi.

Tommy dan Kristianti, Rina Adi. (2018). Pengaruh kepuasan konsumen, harga, kualitas produk, dan promosi terhadap loyalitas merek alat angkat (crane) PT. ABC. Conference on Management and Behavioral Studies. Universitas Tarumanegara

Yudianto,Yefri,(2009).Pengaruh Brand Community Terhadap Loyalitas Merek Sepeda Motor Yamaha, Skripsi, Program Sarjana Psikologi, Sumatera Utara.

\section{INTERNET SOURCE}

https://www.ayooberita.com/berita----2018-pengguna-smartphoneindonesia-tembus-103-juta-orang

https://www.bappenas.go.id/id/beritadan-siaran-pers/peluncuran-bukuproyeksi-penduduk-indonesia-20152045-untuk-pengambilan-kebijakanberbasis-data-akurat/

https://www.cnnindonesia.com/teknol ogi/20140827171919-1851922/redmi-1s-ponsel-pertamaxiaomi-di-indonesia

https://katadata.co.id/berita/2019/08/1 3/riset-canalys-pangsa-pasar-oppomelebihi-samsung-di-indonesia

https://www.medcom.id/teknologi/ne ws-teknologi/8Ky4VyEkmembongkar-jeroan-xiaomi-redminote-7

https://c.mi.com/thread-1704946-10.html

https://c.mi.com/thread-1704713-10.html 
Page: 28-39

ISSN:

DOI:

https://databoks.katadata.co.id/datapublish/2018/ 03/06/2020-penduduk-indonesia-diproyeksi-

mencapai-271-juta-jiwa

https://today.line.me/id/pc/article/5+Brand+Smar tphone+Terlaris+di+Indonesia+Xiaomi+Terus+ Tempel+Samsung-001KOj

https://tekno.kompas.com/read/2019/02/04/1914 0037/separuh-penduduk-indonesia-sudah-melekmedia-sosial 